\title{
Challenges for innovation in health: the Brazilian experience of Public-Private Partnerships for Productive Development in the Economic Industrial Health Complex and Universal Health Coverage context
}

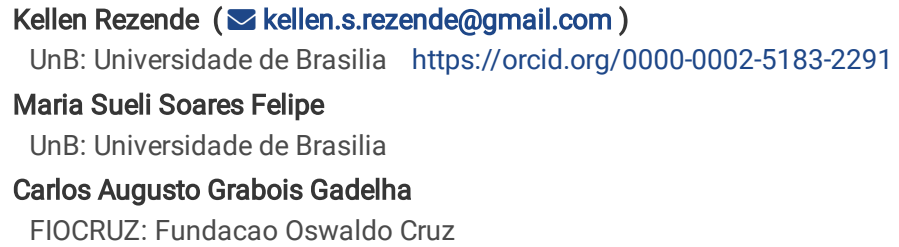

\section{Research}

Keywords: Brazil, Partnerships for Productive Development, Tech transfer, industrial-economic health complex, economic and social development Posted Date: October 14th, 2021

DOI: https://doi.org/10.21203/rs.3.rs-958902/v1

License: (c) (1) This work is licensed under a Creative Commons Attribution 4.0 International License. Read Full License 


\section{Abstract}

Objectives. To provide the conceptual, historical, and normative framework, the analysis of aims and criteria for the establishment of public-private partnerships (Partnerships for Productive Development) in the period of 2009-2020, in the context of the industrial economic complex that serves the Brazilian public health system.

Methods. We presented the conceptual, historical, and normative framework of Partnerships for Productive Development using exploratory and documental bibliography to build an introductory contextual narrative review. We analyzed the objectives from its regulatory framework and the guiding normative criteria of these technology transfer projects. We assigned the Public Health Implications with critical analysis for the establishment of the public-private partnerships in the present context.

Results. For a decade, technology transfer projects for the production of strategic inputs have been established in Brazil. The regulatory framework is established that includes the procedures, objectives, and criteria. The priority objectives originated in 2009, being the main motivators: expansion of access, productive and technological development in the country, and savings for the Ministry of Health. In 2020, 81 projects were in force, including 75 drugs, vaccines, and blood products and six health product projects. Among the drug partnerships, $33 \%$ of the projects are in an effective technology transfer phase. The guidelines and requirements were analyzed in terms of participants, object, intellectual property, schedules, documentation for registration with the National Health Surveillance Agency and certification of production lines, productive integration of the active pharmaceutical ingredient, production process, price, supply capacity, balance exchange, risk analysis, and necessary investments.

Conclusions. The Partnerships for Productive Development present critical aspects for their conclusion considering the priority objectives. The difficulties to carry out the technology transfers in progress for the national production of strategic inputs are the maintenance of the economy for federal public purchases, the national industries production, the actions for monitoring and evaluation, and, finally, can be listed, the reconstruction of political and decision-making governance in the context of the Ministry of Health of Brazil.

\section{Background}

In Brazil, a developing country with a universal health system ${ }^{1}$, public-private partnerships with technology transfer for the promotion of access to strategic products for the Unified Health System (SUS) are named Productive Development Partnerships (PDP) ${ }^{2}$. Public-private partnerships ${ }^{3}$ and strategic alliances between community, academia, and governments ${ }^{4}$ are acknowledged as relevant in countries ${ }^{5}$ that strive to reduce socioeconomic challenges in the context of the United Nations Millennium Development Goals ${ }^{6}$.

The health sector is known for the complexity of inseparable technology and technical-scientific knowledge. There are potentialities of economic development for countries that seek initiatives and policies for the endogenous aggregation of new scientific, productive, and technological capacities, as well as fulfilling needs ${ }^{7}$ of public health ${ }^{8}$, antibiotic resistance ${ }^{9}$, diseases control ${ }^{10}$, nutrition ${ }^{11}$, maternal-child health ${ }^{12}$ and epidemics $^{13}$.

There are valid perceptions that consider PDP as a public policy program for the development of the Brazilian Economic Industrial Complex of Health (CEIS). It is relevant the continuous interest of actors involved: private firms and public institutions, governmental agencies, funders, regulators, public policies designers, managers, and researchers. This initiative is maintained even in political environments of great changes in the governmental priorities and threats to the continuity of achievements in the defense of the Brazilian Constitution as universal right to health ${ }^{14}$.

Above all, it is considered that partnerships are complex systems based on diversified relationships, a myriad of actors with divergent agendas and backgrounds, which influences the governance and the construction of relationships ${ }^{13}$. There was an aggregation of public and private efforts to establish endogenous capacities of the technological frontier, including biopharmaceuticals, immunotherapies, advanced therapies, materials, and equipment in the context of the fourth technological revolution ${ }^{15,16,17}$.

PDP product acquisition in the context of these partnerships registered in 2015 an economy of USD 421,1 million (1 USD = R\$ 5.32) in public purchases ${ }^{18,19}$ centralized by the Ministry of Health. More recent data from the Ministry of Health show an economy of USD 1,3 billion in purchases from 2010 to 2017 in a volume of nearly USD 4 billion ${ }^{20}$, demonstrating an evolution in the process of technology transfer. Presently, there are 19 public institutions, 50 private entities, and 26 national firms conducting PDP projects.

Public policies are assessed through methodologies that confer validity to the outcomes with the use of methods and measures of efficacy, effectiveness, and quality ${ }^{19,21}$. The aim of public policies is to reduce the population's suffering, rather than using ideal plans that are distant from their realities ${ }^{22}$. The citizen perceives public policies as efficient when the outcomes are perceptible and when having access to results ${ }^{23}$ and promotion of knowledge ${ }^{24}$.

The main objectives of this paper are to provide the conceptual, historical, and normative framework, the analysis of aims and criteria for the establishment of PDP in the period of a decade (2009-2020), in the context of the industrial economic complex that serves the Brazilian public health system.

\section{Methods}

The first step was to present the conceptual, historical, and normative framework of PDP, using exploratory and documental bibliography to build an introductory contextual narrative review in the scenery of the pharmaceutical production and the universal public health system in Brazil. 
The next step was to analyze the objectives, directives, and requirements (criteria) for the establishment of PDP considering the regulatory framework. It was possible to make the correlation with the principles of strengthening of CEIS, broadening the access to products considered strategic for public health, productivity, technological development, and economy in public federal purchases. Then Public Health Implications were analyzed.

\section{Results}

\section{Conceptual, historical, and normative framework of PDP}

The first PDP projects were approved by the Ministry of Health of Brazil in 2009 for local production of drugs, vaccines, blood, and health products considered strategic for SUS. The basic model involved the participation of at least three partners. It should mandatorily comprise a public institution (receiver of the technology of the finished product, responsible for the presentation of the project to the Ministry of Health and the technology internalization in its industrial park); a private entity (a national or international holder of the technology to be transferred to the Brazilian public institution); and a public or private laboratory (producer of the active pharmaceutical ingredients - API, established in Brazil).

Following the regulation, public partners establish partnerships with private entities, holders of technology or knowledge, to develop strategic products for SUS. Public laboratories are responsible for the coordination of the partnership with their private partners. Purchases are carried out by the Ministry of Health during the technology transfer term, in a public commitment signed with the public laboratories. There is a guarantee of the public market during the knowledge transfer term, when there should occur the qualification of the public laboratory for the local production, with the follow-up and tutorial of the private partners.

Presently, there are 81 ongoing PDP involving technology transfer and national production of 75 drugs, vaccines, and blood products, and another six PDP of health products. Among the partnerships for drugs, vaccines, and blood products, eight are in Phase I (PDP project proposal), 43 in Phase II (PDP project), 24 in Phase III (PDP). Suspended partnerships represent 24\% (18) of the partnerships, with 67\% in Phase II and 33\% in Phase III (Figure 1).

Figure 1. Ongoing and suspended PDP for drugs, vaccines, and blood products per PDP phase - 2019.

Among the partnerships for health products, one is in Phase I, six are in Phase II and three are in Phase III. Suspended PDPs represent 50\% (Figure 2).

Figure 2. Ongoing and suspended PDPs for health products per PDP phase - 2019.

There are 11 PDP for drugs, vaccines, and blood products classified in Phase IV by the Ministry of Health; no PDP for health products has reached this phase yet. Phase IV is characterized as that in which the official public laboratories confirm the conclusion of the internalization of technology in their industrial parks for production technology and the finished drug or health product, as well as the APIs by the pharmaceutical or the biological producer.

\section{Analysis of PDP objectives}

PDP objectives were originated in 2009 and incorporated into the subsequent normative bearing the social and economic vision as needs foreseen by health policies and the Brazilian industrial development. The objectives are hereafter systematized into three main goals.

Broadening of access: the main PDP objective is to enlarge the population's access to public health strategic products by increasing the purchased volumes to attend pharmaceutical assistance programs, aiming, in the end, to treat more patients ${ }^{25}$.

Productive and technological development. to reduce the country's productive, technological, and economic dependence to fulfill health needs in the short-, medium- and long-term, complying with the constitutional principles of universal and equitable access to actions and services of health. Also, to stimulate knowledge interchange for innovation to CEIS development; to promote the manufacturing of strategic products for SUS and contribute to commercial deficit reduction, and to stimulate the development of national producers network. In the end, it aims to reduce Brazilian historical dependence on finished products with a high aggregate value in a globalized economy, in which market oscillations, wars, pandemics, and environmental events can have damaging effects in a developing country.

The economy in public federal purchases: to rationalize the State's purchasing power through a selective centralization of expenditure aiming at SUS sustainability and the increase of strategic products manufacturing in the country; to protect the society by seeking economics, considering the price, quality, technology, and social benefits.

\section{Directives and requirements (criteria) for the establishment of PDP}

PDP projects must observe criteria regarding participant subjects; object; intellectual property; executive project terms/schedule; registration and certification; productive integration degree; production process; sale price proposal and supply capacity estimation; currency balance; risk analysis; and necessary investments for the concretization of projects.

I- Participants: the presence of one or more public institutions responsible for technology absorption and product manufacturing and one or more private entities, holders, or developers of the product's technology, responsible for technology transfer to a public institution. It is expected acceleration of nonexistent technology internalization process in the country, including product, process, and organizational innovations ${ }^{26}$.

Local synthetic or biological active pharmaceutical ingredients (APIs) producers, public or private entities, and also health product critical components producers must participate in the formation of a partnership. 
In 2020, the PDP projects were distributed among 52 partners, of which 15 were public and 37 were private. Of the totality of private partners, 10 firms were of national origin and 14 firms were of multinational origin.

II - Objects: the products listed as strategic products for SUS are eligible for development, transfer, and absorption of technology ${ }^{16}$ as PDP. The List of Strategic Products of SUS should not be confounded with other lists developed to provide for several public policies, such as the National List of Essential Drugs (RENAME), which refers to the national list of essential drugs as required by the World Health Organization (WHO $)^{26}$.

III - Intellectual property: research, development, and manufacturing of products to be purchased as PDP must comply with the legislation in force, i.e., will comply with the validity period of the patent granted by the National Institute of Industrial Property (INPI) in the national territory. Before each PDP approval, there is the verification of the number of patents granted or being processed for each molecule being analyzed.

$I V$ - Executive project terms/schedules: for execution, four phases are proposed: 1) elaboration, presentation, and analysis of the "PDP project proposal"; 2) implementation of the "PDP project" approved to grant the registration of the product, start the purchase by the Ministry of Health and carry out the technology transfer; 3) stage of "PDP" with technology transfer between public and private partners until the finalization of the technology transfer process, and 4) technology internalization in the country and knowledge portability by the public institution.

The maximum duration term should be proposed based on the complexity of the technology internalization and should not be longer than ten years. This complexity is based on productive processes difficulties faced by public or private institutions responsible for the national production of the active, biological, or synthetic pharmaceutical ingredient, or the critical technological component.

For example, processes that involve biological ingredients are more complex for national producers. This productive platform installation is under progress in the country yet and, for this reason, projects for biological products have been approved for over five years and less than ten years with effective purchases from the Ministry of Health.

The schedule presented should involve the prediction of budget and responsibilities; be compatible with the facilities and equipment specifications to the tech transfer. A special aspect is the adequacy of industrial installations to comply with sanitary regulations.

$V$ - Registration and certification: public institution and private entity products sanitary registration, as well as its regulatory post-registration stages, should be prioritized in a PDP. Considering the complex steps to complete a tech transfer involving biological and pharmaceuticals ingredients the regulatory impact cannot be neglected. These steps include license renewals and Good Manufacturing Practices (GMP) Certifications.

VI - Productive integration degree: one of the main criteria for a new PDP approval is the promise to effectuate the tech transfer. It must be within the stipulated time and must complete the synthetic or biological API knowledge transfer for local production, as well as the critical technological components.

It is highly recommended access to public partners to the Drug Master File (DMF) for synthetics products and the Master Cell Bank (MCB) for biological/biosimilar products. In the case of health products, to the complete critical technological component for knowledge production.

VII - Production process: the production flow plan should be presented in detail, including the aspects of infrastructure adequations, with an indication of whether the production facilities of the partners involved will need new investment; the appropriate conditions to carry out the project, including procedures, and organizational resources.

When necessary, infrastructure adjustments should be specified by the public institution in the executive project, as well as data on needed resources, budgeted costs, and estimation of the conclusion of critical investments to make the PDP feasible for all partners. The necessary equipment for the production process and quality control should be described in the PDP executive project, informing the nominal capacity, whether the partners already have the needed equipment, or present an estimation of the purchase/spending with the respective specification of funding sources.

There should also be a specification of necessary human resources to carry out the management, development, and technological absorption process and quality assurance, with the indication of numbers, and necessary training and qualification.

VIII - Sale price proposal and supply capacity estimation: proposals should present sales nominal unit values and the annual supply capacity for the period of the tech transfer project. Proposed prices should be compatible with commercial practices and if necessary also with international market prices of countries considered by the Brazilian Drugs Market Regulation Chamber (CMED).

The sales prices should decrease every year during the effective tech transfer phase. The values presented must consider, on an actual basis, the variation of the National Consumer Price Index (IPCA) or the sector price index and the exchange rate variation, according to CMED regulation.

The construction of the sale price proposal and the supply capacity estimation should use the Ministry of Health's average prices registered at official banks: Health Prices Bank (BPS) and the Integrated System of General Services Administration (SIASG). The sale price reference for the debutant PDP purchase should consider the Ministry of Health's last sale price paid for the product, published in the federal official journal.

Other data sources should also be used: price registry minutes, SUS national health data, official average prices practiced in the national and international market databases, Drugs Market Follow-up System (SAMMED) of CMED, Revolving Fund of Pan-American Health Organization (PAHO), and Global Fund to Fight AIDS, Tuberculosis, and Malaria.

For innovative products, the final product price should consider the international average prices practiced in countries listed by CMED. For those products that the patent will expire during the phases of the tech transfer, a study should be presented containing an analysis in which the projections of price reduction are 
compatible with the changes in market levels.

IX - Foreign exchange balance: an evaluation should be made involving the finished product, APIs and, intermediary technological components to the foreign exchange balance. The methodology used for annual currency economy estimation during the tech transfer phases should also be declared.

$X-P D P$ risk analysis: risks related to tech transfer processes must be enlightened by the public partner concerning production, regulatory, and management processes aspects, using some owned methodology.

$X I$ - Investments: investments must be consistent with the capacity and financing sources. They should consider infrastructure adaptations, new equipment, staff recruitment, and training. Public partners should consider sales profit carried out with the Ministry of Health as a financing source during the tech transfer. Ministry of Health does not participate directly in this funding. Private partners must seek their funding as investments.

New PDP project proposals are analyzed according to the criteria presented above. It is also considered the accordance with SUS public policies implemented for health promotion, prevention, and care. Proposals are also analyzed concerning their importance for scientific, technological, and socioeconomic development. The absence or insufficiency of national production or shortage risk of the finished product, API, or critical technological component, contributes to the reasonable approval of a new PDP in the context of Brazilian CEIS.

\section{Discussion}

This study conceptually details the requirements for establishing PDPs and clearly presents the objectives that must be pursued to achieve success, which are summarized as follow.

\section{Finishing the tech transfer}

the accomplishment of this step ensures knowledge retention in the national industrial park. It also contributes to the main PDP objective, which is to avoid strategic products shortage due to international market oscillations.

\section{National production of the critical technological input}

production in the country of the critical technological ingredient, known as the API, or the critical technological component (equipment and materials) also ensures SUS sustainability.

\section{Ministry of Health's economy on public purchases}

it might be considered public gains regarding the economy in federal purchases and foreign exchange balance.

\section{National production of biosimilars}

achieve the national production of biosimilars proposed with PDP projects since 2013 reaching the establishment in the country of the biological production platform, with the internalization of Master Cell Banks.

Maintenance of technical and analytical governance in the decision-making process: It can be inferred that PDP governance is reduced when the following occurrences are verified: publication of new norms that promote the redistribution of participation rates of public and private partners without the due technical evaluation of the technical evaluation and decision commissions; political opportunity and appropriation of the outcomes of projects and consequent (unjustified) changes to fulfill non-collective interests; reduction of technical participation in debates held within the analyses commissions; reduction of the importance of technical regulatory committees; biased understanding of articles in the regulatory framework in favour of non-collective interests; proposition of changes in the regulatory framework without previous collective, technical debate and public consultation with sectors involved in CEIS; unilateral decision-making by the Ministry of Health, without hearing the other Ministries involved in the assessment and monitoring of PDP.

The demands for high aggregate value inputs purchased in a centralized way by the Ministry of Health are incorporated, since 2009, into strategic product lists that function as public orders and guide the productive sector in the sense of the national development of its public productive base and that of CEIS. Therefore, it is necessary that the elaboration of these lists is adjusted to the objectives of PDP and that their construction is based on evidence, with the support of interactions like academia-government-entrepreneurs ${ }^{16}$. Furthermore, it should be considered in the elaboration of these lists: future strategic products; utilization of multi-criteria matrix; technological horizon evaluation; prioritization of products for neglected diseases treatment, disease impact (burden, disease prevalence and severity, therapeutical necessity, and clinical practice variation) ${ }^{17}$.

However, it should be stressed that conducting PDP should not reduce efforts for the development of other forms of endogenous development of technology creation achieved by the basic, laboratory, or academic research that reaches non-clinical and clinical development for the registration of new molecules strategically developed in the country.

\section{Conclusion}

A detailed explanation of directives and requirements has been presented in this study for the clarification of key aspects for tech transfer approval and conducting. PDP has gained great significance in the pharmaceutical scenery and the national SUS in Brazil, largely due to the importance of public resources involved and the use of purchasing power. The health sector is intense in technology, competition, and complexity. The search for mechanisms and policies to 
induce the national production towards the reduction of vulnerabilities of SUS has led to a relevant performance of CEIS, though without the due regulatory follow-up that would characterize PDP as public policy.

\section{Abbreviations}

API - Active Pharmaceutical Ingredients

BPS - Health Prices Bank

CEIS - Brazilian Economic Industrial Complex of Health

CMED - Brazilian Drugs Market Regulation Chamber

DMF - Drug Master File

GMP - Good Manufacturing Practices

INPI - National Institute of Industrial Property

IPCA - National Consumer Price Index

MCB - Master Cell Bank

PAHO - Pan-American Health Organization

PDP - Productive Development Partnerships

RENAME - Brazilian National List of Essential Drugs

SAMMED - Drugs Market Follow-up System

SIASG - Integrated System of General Services Administration

SUS - Unified Health System

WHO - World Health Organization

\section{Declarations}

Ethics approval and consent to participate: Not applicable

Consent for publication: Not applicable

Availability of data and materials: Not applicable

Competing interests: The authors declare that they have no competing interests

Funding: Not applicable

Authors' contributions: Kellen Santos Rezende has drafted the work; Maria Sueli Soares Felipe has approved the submitted version; Carlos Augusto Grabois Gadelha has agreed both to them personally accountable for his contributions and to ensure that questions related to the accuracy or integrity of any part of the work, even ones in which he is not personally involved, are appropriately investigated, resolved, and the resolution documented in the literature.

Acknowledgments: Not applicable

\section{References}

1. Jamison DT, Gelband H, Horton S, et al., editors. Disease Control Priorities: Improving Health and Reducing Poverty. 3rd edition. Washington (DC): The International Bank for Reconstruction and Development / The World Bank; 2017 Nov 27. Available from: https://www.ncbi.nlm.nih.gov/books/NBK525289/ doi: 10.1596/978-1-4648-0527-1

2. Silva GO, Rezende K. Partnerships for productive development: the establishment of socio-technical networks in the Economic-Industrial Complex of Health. Vigil. sanit. Debate. 2017;5(1):1-1. https://doi.org/10.3395/2317-269X.00807. https://periodicos.fiocruz.br/pt-br/publicacao/1531019

3. Iovan S, Lantz PM. Social Impact Bonds: A Promising Public-Private Partnership Model for Public Health. Am J Public Health. 11 de julho de 2018;108(8):e6-e6. DOI: 10.2105/AJPH.2018.304548. https://www.ncbi.nlm.nih.gov/pmc/articles/PMC6050856/

4. Erwin PC, Parks RG, Mazzucca S, et al. Evidence-Based Public Health Provided Through Local Health Departments: Importance of Academic-Practice Partnerships. Am J Public Health. March 21, 2019;109(5):739-47. https://doi.org/10.2105/AJPH.2019.304958

Page 6/8 
5. Thiessen J, Bagoi A, Homer C, Rumsey M. Qualitative evaluation of a public-private partnership for reproductive health training in Papua New Guinea [Internet]. 2018 [cited on April 19, 2020]. DOI: 10.22605/RRH4608. https://pubmed.ncbi.nlm.nih.gov/30543754/

6. Bzdak M. The Collaboration Challenge: Global Partnerships to Achieve Global Goals [Internet]. World Health \& Population. 2017 [cited on April 20, 2020]. DOI: $10.12927 /$ whp.2017.25303

7. Knai C, Petticrew M, Douglas N, et al. The Public Health Responsibility Deal: Using a Systems-Level Analysis to Understand the Lack of Impact on Alcohol, Food, Physical Activity, and Workplace Health Sub-Systems. Int J Environ Res Public Health. December, 2018;15(12):2895. DOI: 10.3390/ijerph15122895

8. Grant JH, Handwerk K, Baker K, Milling V, Barlow S, Vladutiu CJ. Implementing Group Prenatal Care in Southwest Georgia Through Public-Private Partnerships. Matern Child Health J. November 1st, 2018;22(11):1535-42. DOI: 10.1007/s10995-018-2576-0

9. Lomazzi M, Moore M, Johnson A, Balasegaram M, Borisch B. Antimicrobial resistance - moving forward? BMC Public Health. 2 de julho de 2019;19(1):858. https://bmcpublichealth.biomedcentral.com/articles/10.1186/s12889-019-7173-7

10. Sakamoto H, Lee S, Ishizuka A, et al. Challenges and opportunities for eliminating tuberculosis - leveraging political momentum of the UN high-level meeting on tuberculosis. BMC Public Health. 16 de janeiro de 2019;19(1):76. https://bmcpublichealth.biomedcentral.com/articles/10.1186/s12889-019-6399$8 /$ metrics

11. Drewnowski A, Caballero B, Das JK, French J, Prentice AM, Fries LR, et al. Novel public-private partnerships to address the double burden of malnutrition. Nutr Rev. 10 de novembro de 2018;76(11):805-21. doi:

10.1093/nutrit/nuy035. https://www.ncbi.nlm.nih.gov/pmc/articles/PMC6236421/\#: :text=Public\%E2\%80\%93private\%20partnerships\%20are\%20an,sector\%2

12. El Bcheraoui C, Kamath AM, Dansereau E, et al. Results-based aid with lasting effects: sustainability in the Salud Mesoamérica Initiative. Glob Health. 16 de outubro de 2018;14(1):97. https://globalizationandhealth.biomedcentral.com/articles/10.1186/s12992-018-0418-x

13. Harrison K, Robinson J, Marks L, Blander J, McDermott P. ACTing in Partnership to Accelerate Impact. Jaids J Acquir Immune Defic Syndr [Internet]. August 15, 2018 [cited on April 19, 2020];78. DOI:

10.1097/QAI.0000000000001729. https://journals.Iww.com/jaids/fulltext/2018/08152/acting_in_partnership_to_accelerate_impact.2.aspx

14. Magno LD, Paim JS. Dos clamores das ruas aos rumores no Congresso: uma análise da conjuntura recente da saúde no Brasil. Rev Eletrônica Comun Informação Inov Em Saúde [Internet]. December 18, 2015 [cited on May 26, 2017];9(4).

DOI: https://www.reciis.icict.fiocruz.br/index.php/reciis/article/view/1043

15. Temporão JG, Gadelha CAG. The Health Economic-Industrial Complex (HEIC) and a New Public Health Perspective [Internet]. Oxford Research Encyclopedia of Global Public Health. 2019 [cited on April 21,

2020]. https://oxfordre.com/publichealth/view/10.1093/acrefore/9780190632366.001.0001/acrefore-9780190632366-e-27

16. Rezende KS, Silva G de O, Albuquerque FC, Rezende KS, Silva G de O, Albuquerque FC. Productive Development Partnerships: an essay on the construction of strategic product lists. Saúde em Debate. novembro de 2019;43(SPE2):155-68. DOI: 10.1590/0103-11042019S212

https://www.scielo.br/j/sdeb/a/SHFtz7JyvrB6B7H9ysxTQ4p/?format=pdf\&lang=en

17. Silva G de O, Elias FTS. Parcerias para o Desenvolvimento Produtivo: uma proposta de monitoramento estratégico. Saúde em Debate. novembro de 2019;43(SPE2):217- 33. https://www.scielo.br/j/sdeb/a/3KcGyhqDjdr8P3m4TPCWnXP/abstract/?lang=pt

18. Oliveira EJV, Vivan AL, Albuquerque FC, et al. A consolidação do marco regulatório das parcerias para o desenvolvimento produtivo. Gestão e Saúde. 13 de agosto de 2015;6(4):Pág. 3175-3193. https://periodicos.unb.br/index.php/rgs/article/view/3320/3005

19. Donabedian A. The Role of Outcomes in Quality Assessment and Assurance. QRB - Qual Rev Bull. 1o de novembro de 1992;18(11):356-60. doi: 10.1016/s0097-5990(16)30560-7. https://pubmed.ncbi.nlm.nih.gov/1465293/

20. Ações desenvolvidas no âmbito das Parcerias para o Desenvolvimento Produtivo (PDP) 2017/2018. http://www.abifina.org.br. Published November 09, 2018. Accessed February 23, 2021

21. WHO. A health policy analysis reader: The politics of policy change in low- and middle-income countries [Internet]. WHO. [cited on April 21, 2020]. Available at: https://www.researchgate.net/publication/328956928_A_health_policy_analysis_reader_the_politics_of_policy_change_in_low-_and_middleincome_countries_WHO_Geneva

22. Racionalismo crítico. In: Wikipédia, a enciclopédia livre [Internet]. 2017. Available at: https://pt.wikipedia.org/wiki/Racionalismo_cr\%C3\%ADtico

23. Brasil EN de AP. Pierre Zémor fala sobre comunicação pública na ENAP. Rev Serviço Público. 2009;60(2):197-200.

DOI: https://revista.enap.gov.br/index.php/RSP/article/view/22

24. Ibrahim H. Structuring a successful information technology transfer process: A case study from the perspectives of actor network Theory. $J$ Inf Commun Technol. 19 de janeiro de 2020;9:17-39. Available at: http://e-journal.uum.edu.my/index.php/jict/article/view/8097 Date accessed: 28 feb. 2021. 
25. Ahonkhai V, Martins SF, Portet A, Lumpkin M, Hartman D. Speeding Access to Vaccines and Medicines in Low- and Middle-Income Countries: A Case for Change and a Framework for Optimized Product Market Authorization. PLoS ONE [Internet]. 16 de novembro de 2016;11(11). https://journals.plos.org/plosone/article?id=10.1371/journal.pone. 0166515

26. WHO. WHO Model Lists of Essential Medicines [Internet]. WHO. [cited on April 22, 2020]. Available at: https://www.who.int/groups/expert-committee-onselection-and-use-of-essential-medicines/essential-medicines-lists

\section{Figures}

\section{Ongoing PDP - Drugs, Vaccines and Blood Products}

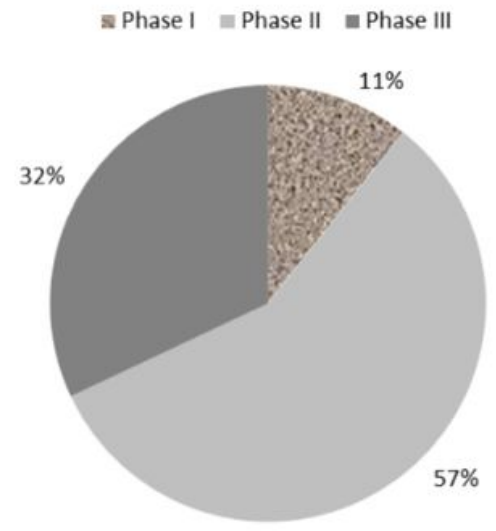

\section{Suspended PDP - Drugs, Vaccines and Blood Products}

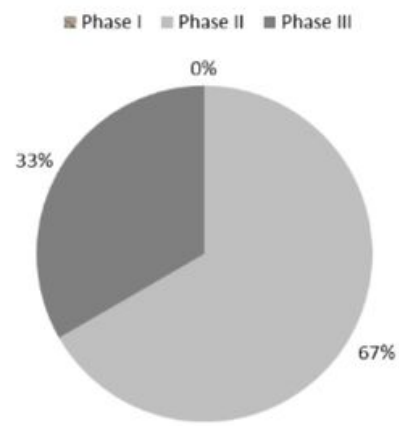

Figure 1

Ongoing and suspended PDP for drugs, vaccines and blood products per PDP phase, in 2019. Source: The author, drawing on data from the Ministry of Health (2019)

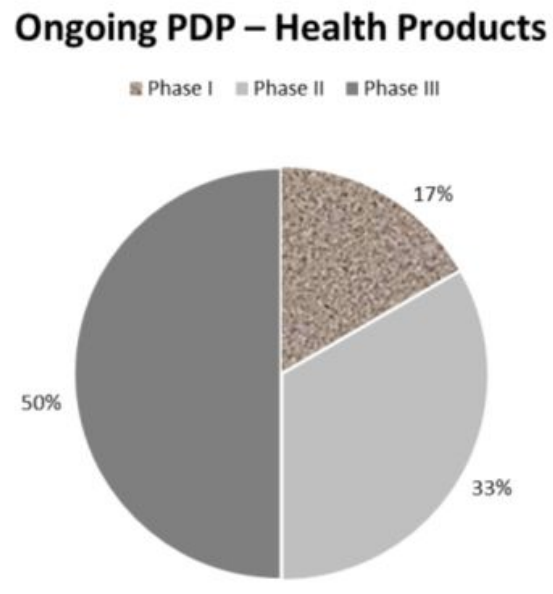

Suspended PDPs - Health Products

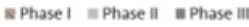

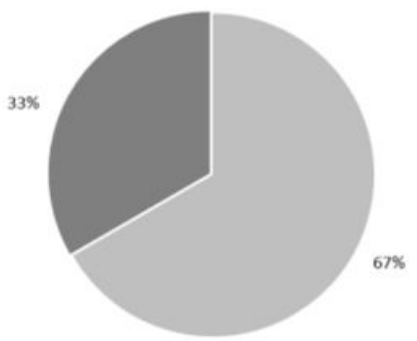

Figure 2

Ongoing and suspended PDPs for health products per PDP phase, in 2019. Source: The authors, drawing on data available at http://www.saude.gov.br/saudede-a-z/parcerias- para-o-desenvolvimento-produtivo-pdp, updated on 21 June, 2019. 